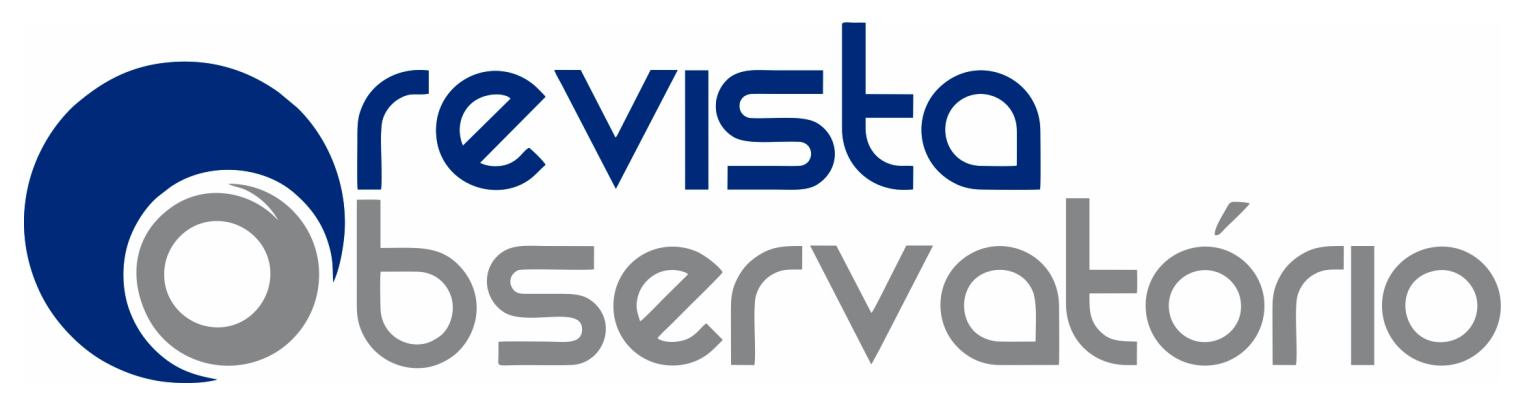

CARRY FIRE: um estudo de recepção das críticas musicais ao disco de Robert Plant
CARRY FIRE: a study of reception of musical criticisms of Robert Plant's álbum

CARRY FIRE: un estudio de recepción de críticas musicales del álbum de Robert Plant

\title{
Fábio $\mathrm{Cruz}^{1}$ \\ Arthur Freire Simões Pires ${ }^{2}$
}

\section{RESUMO}

Neste artigo, realizamos um estudo voltado à compreensão de como receptores, que cursaram uma disciplina universitária, que une comunicação com o gênero musical rock, compreendem as críticas musicais, entendidas como um subgênero do jornalismo cultural (PIZA, 2013). Sob preceitos de Kellner (2001) e Orozco Gómez (2000), analisamos o debate com o grupo focal acerca de dois textos produzidos pelos veículos The Guardian (Inglaterra) e Omelete (Brasil). Entendemos que os textos reforçam estereótipos, fator este que corrobora um posicionamento contrário por parte dos receptores em relação ao conteúdo dos textos selecionados.

\footnotetext{
${ }_{1}^{1}$ Pós-doutor em Direitos Humanos, Mídia e Movimentos Sociais (Universidade Pablo de Olavide - UPO, Sevilha, Espanha). Doutor em Cultura Midiática e Tecnologias do Imaginário pela Pontifícia Universidade Católica do Rio Grande do Sul (PUCRS). Professor do curso de graduação em Jornalismo da Universidade Federal de Pelotas (UFPel). E-mail: <fabiosouzadacruz@gmail.com> 2 Jornalista formado pela Universidade Federal de Pelotas. Universidade Federal de Pelotas. Email: grohsarthur@gmail.com.
} 


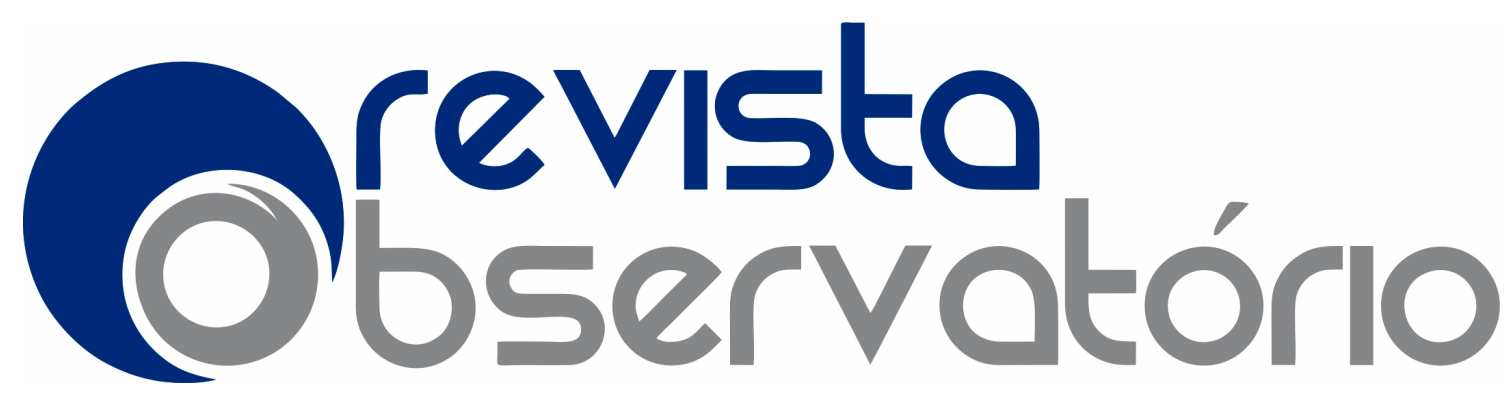

ISSN n² 2447-4266

Vol. 5, n. 6, Outubro-Dezembro. 2019

DOI: http://dx.doi.org/10.20873/uft.2447-4266.2019v5n6p453

PALAVRAS-CHAVE: Crítica musical; recepção; rock; Robert Plant.

\begin{abstract}
In this article, we accomplished a study turned at understanding how receptors, that attended the course of Rock's Social History, which unites communication with the musical genre rock, comprehend the musical reviews, understood as cultural journalism's subgenre (PIZA, 2013). With precepts Kellner's (2001) and Orozco Gómez's (2000) precepts, we analyzed the debate with a focus group about two texts by The Guardian (England) and Omelete (Brazil). We understand that the reviews reinforce stereotypes, which corroborates an opposing positioning by the receptors regarding the selected text's content.
\end{abstract}

KEYWORDS: Musical criticism; reception; rock; Robert Plant.

\title{
RESUMEN
}

En este artículo, llevamos a cabo un estudio destinado a comprender cómo los receptores, que asistieron a una disciplina universitaria, que une la comunicación con el género musical de rock, comprenden las críticas musicales, entendidas como un subgénero del periodismo cultural (PIZA, 2013). Bajo los preceptos de Kellner (2001) y Orozco Gómez (2000), analizamos el debate con el grupo focal sobre dos textos producidos por los vehículos The Guardian (Inglaterra) y Omelete (Brasil). Entendemos que los textos refuerzan los estereotipos, un factor que corrobora una posición opuesta por parte de los destinatarios en relación con el contenido de los textos seleccionados.

PALABRAS CLAVE: Crítica musical; recepción roca Robert Plant.

Recebido em: 01.06.2019. Aceito em: 09.09.2019. Publicado em: 01.10.2019. 


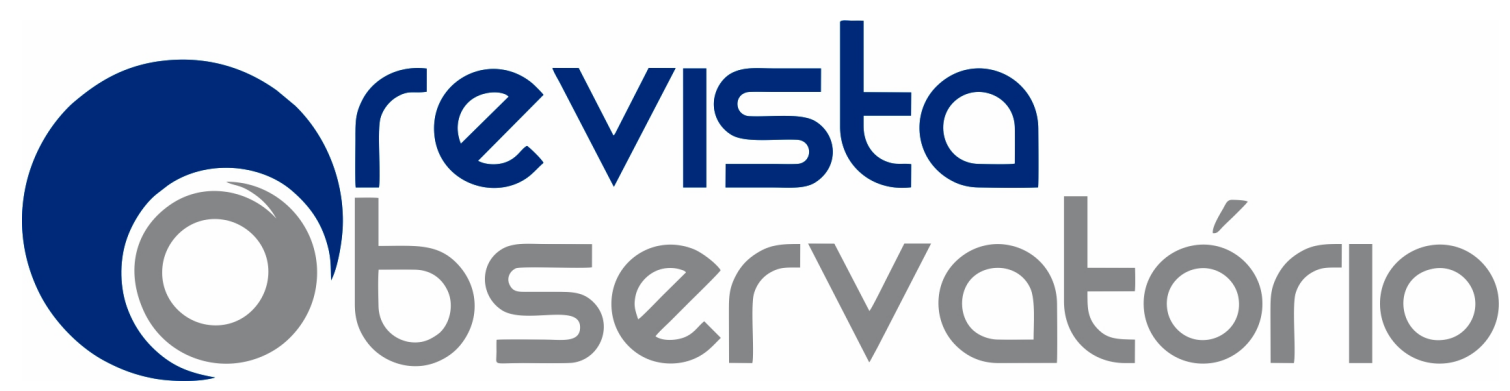

ISSN n² 2447-4266

Vol. 5, n. 6, Outubro-Dezembro. 2019

DOI: http://dx.doi.org/10.20873/uft.2447-4266.2019v5n6p453

\section{Dos objetos e dos conceitos iniciais}

Em outubro de 2017, mais precisamente, no décimo terceiro dia do mês, o icônico cantor Robert Plant lançou seu décimo primeiro trabalho de estúdio, intitulado Carry Fire. Já consagrado, o artista carrega consigo números de vendas expressivos $^{3}$ e atrai vários fãs, que conquistou com o legado de seus trabalhos anteriores e com sua carreira solo.

Nascido em West Bromwich, Inglaterra, o vocalista tem uma grande bagagem de vida, ascendendo para o mundo junto com sua antiga banda (o Led Zeppelin), mundialmente conhecida e com números expressivos em vendas de disco. Plant, ao lado de Jimmy Page (guitarrista), John Paul Jones (baixista e tecladista) e John Bonham (baterista, este falecido em 1980), teve sua união musical homenageada e eternizada pelo Rock'N'Roll Hall of Fame ${ }^{4}$, em 1995, numa cerimônia que sacramentou o nome deles e da banda para toda a história, fazendo parte do panteão de artistas que estampa as dependências do local.

Após o fim do Led Zeppelin, com o falecimento de Bonham, Plant apostou em sua carreira solo, que permanece até hoje. Desde 2012, o músico inglês é acompanhado pela banda Sensational Space Shifters, com dois discos lançados nesta parceria, a saber: Lullaby and the Ceaseless Roar, de 2014, e Carry Fire (que faz parte e dá nome ao nosso estudo).

\footnotetext{
${ }^{3}$ Segundo a revista FORBES, somente o Led Zeppelin, vendeu mais de 300 milhões de cópias. Como Plant é um membro fundador e esteve do início ao fim na banda, os números são contabilizados em sua carreira. Os dados são impressionantes e não é necessário levar em consideração sua carreira solo para comprovar a expressividade com o público e aclamação sobre seu trabalho para pontuar o sucesso de vendas que é. Disponível em <https://www.forbes.com/sites/markbeech/2018/01/27/led-zeppelin-adds-to-300-million-saleswith-live-album-50th-anniversary-surprises/\#116ea753ca59>. Acessado em 10 out. 2018.

4 Hall da Fama do Rock'N'Roll, localizado em Cleveland, Ohio. Disponível em <https://www.rockhall.com/inductees>. Acessado em 5 jan. 2019.
} 


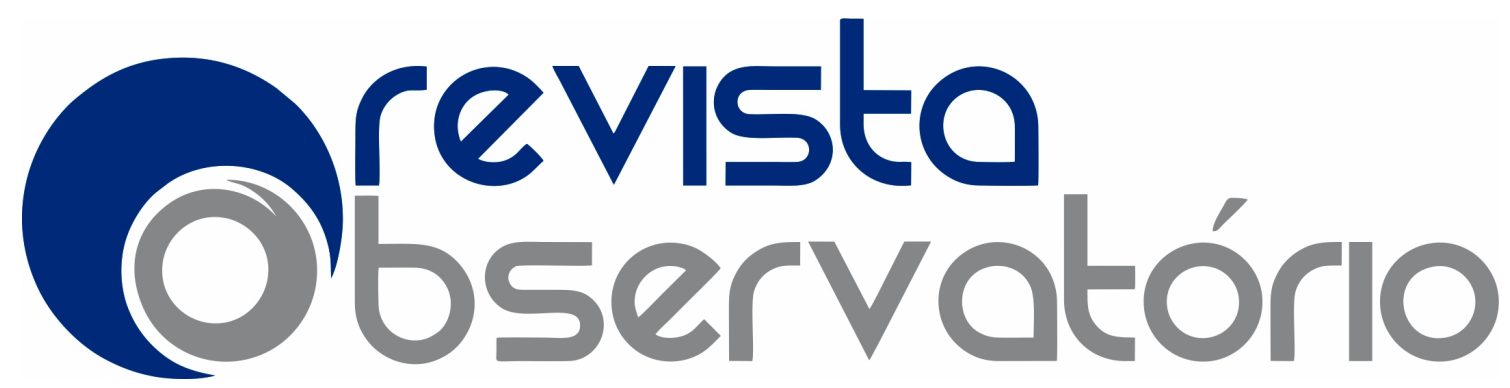

O jornalismo tem como capacidade, aproximar o público-consumidor de pautas e conteúdos, conectando, então, o músico e sua obra com fãs que tem uma grande distância física. Partindo da forma que divulga acontecimentos, debate, comenta e/ou os aborda (no caso do estudo que tratamos aqui, o lançamento do long-play), o exercício jornalístico dá informações para quem as busca, deixando o apreciador mais próximo (em uma visão conteudista - de ter conhecimento do conteúdo) em relação ao seu ídolo.

Por se tratar de uma produção que tange o espaço cultural (na oportunidade, música), cabe aos espaços de jornalismo cultural abordarem, consequentemente. Neste sentido, buscamos, então, conceitos e discussões acerca do jornalismo cultural para a discussão e a conseqüente reflexão que serão trabalhadas neste estudo. Partindo de uma abordagem de Piza (2013), traremos significados e preceitos propositivos da crítica cultural, que serão explicados na sequência.

Acima de tudo, o jornalismo cultural é um gênero jornalístico, por óbvio. Então, existe o objetivo básico de informar. Durante a leitura da obra do ator supracitado, percebemos que ele salienta o papel da crítica (ou resenha) dentro desse espaço do jornalismo. ${ }^{5}$

Selecionamos duas críticas, uma do país natal do cantor - publicada em um dos principais veículos jornalísticos do planeta, The Guardian - e a outra do portal brasileiro Omelete (que, na época, era ligado ao site UOL, um dos mais acessados pelo público brasileiro). O site é conhecido por ser um dos principais canais de conteúdo da cultura pop da internet brasileira - escolhido exatamente

\footnotetext{
${ }^{5}$ Ao longo do trabalho, aprofundaremos a ideia aqui posta.
} 


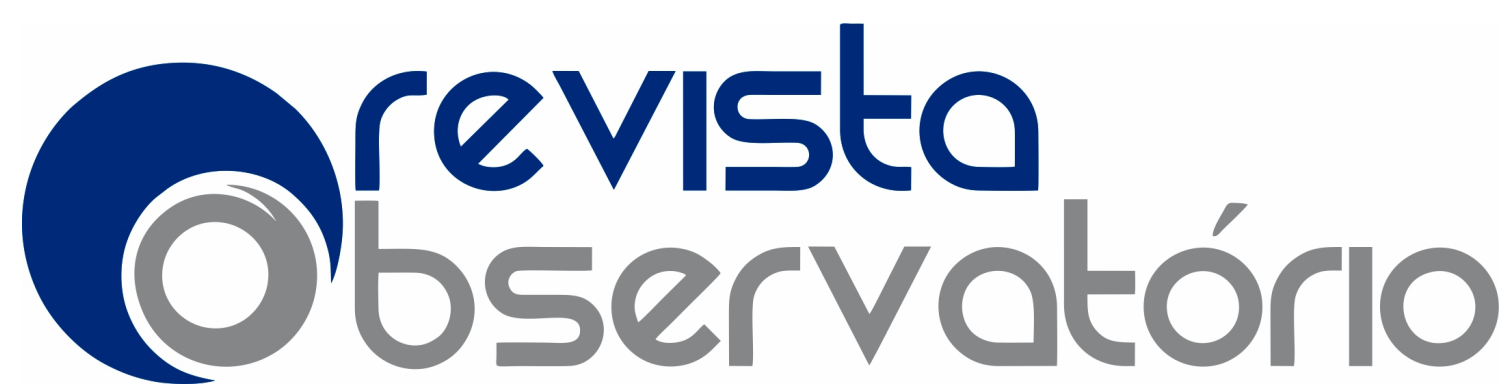

ISSN n² 2447-4266

Vol. 5, n. 6, Outubro-Dezembro. 2019

DOI: http://dx.doi.org/10.20873/uft.2447-4266.2019v5n6p453

por sua popularidade entre o público que consome conteúdo do jornalismo cultural.

Os textos selecionados foram retirados de portais virtuais ${ }^{6}$, que se enquadram na classificação de webjornalismo ${ }^{7}$. Neste sentido, segundo Cruz e Curi (2015), o webjornalismo nasce do jornalismo impresso durante o início da era digital. Ainda segundo os autores,

com o surgimento da rede mundial de computadores, conhecida pela sigla "www", os noticiosos impressos, aos poucos, foram migrando para o mundo virtual. Num primeiro momento, as reportagens eram cópias fidedignas do que havia sido divulgado no veículo tradicional. Com o passar do tempo, são criados conteúdos próprios para internet e são inseridos outros tipos de mídia para complementar a escrita: vídeos, fotos, hiperlinks. (CRUZ; CURI, 2015, p. 4)

Então, a manifestação do jornalismo cultural, por meio do seu subgênero - que é a crítica - dá-se por meio de uma plataforma da internet. Partindo daí, entendemos que o jornalismo cultural não foge dos preceitos do que o próprio jornalismo propõe. Para Piza (2013), a produção jornalística da seção de cultura deve ultrapassar a ideia de informar.

Especificamente, em um texto de crítica, Piza (2013, p. 70) explica que devem estar presentes

Primeiro, todas as características de um bom texto jornalístico: clareza, coerência e agilidade. Segundo, deve informar ao leitor o que é a obra ou o tema em debate, resumindo sua história, suas linhas gerais, quem é o autor etc. Terceiro, deve analisar a

\footnotetext{
${ }^{6}$ Apesar do The Guardian ser um jornal tradicional e extremamente relevante para o meio jornalístico, não conseguimos acesso à sua versão impressa mas, sim, à versão digital, atualizada diariamente. Portanto, na perspectiva trabalhada, o conteúdo que selecionamos se enquadra como webjornalismo.

7 Dentro do jornalismo, os produtos do ofício podem ser publicados dentro de materiais impressos (tais quais revistas e jornais), rádios, portais dentro da web, televisão etc. No caso, estamos tratando de dois produtos produzidos dentro de um site, configurando-se, então, como uma plataforma web.
} 


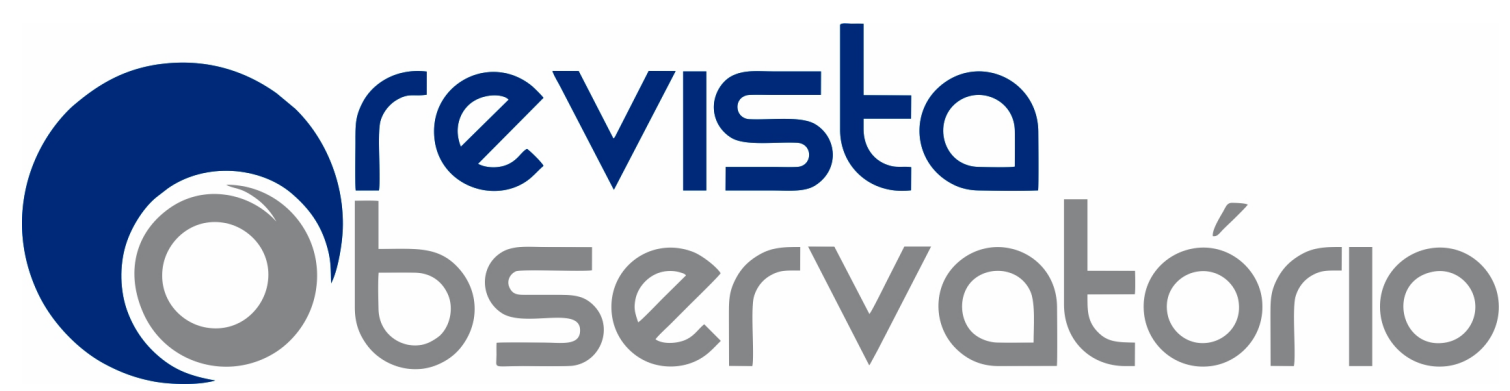

ISSN n² 2447-4266

Vol. 5, n. 6, Outubro-Dezembro. 2019

DOI: http://dx.doi.org/10.20873/uft.2447-4266.2019v5n6p453

obra de modo sintético mas sutil, esclarecendo o peso relativo de qualidades e defeitos, evitando o tom de "balanço contábil" ou a mera atribuição de adjetivos.

Na sequência, o autor explica um quarto requisito para se escrever uma resenha crítica jornalística que é, simplesmente, não ficar totalmente atrelado à obra, mas retirar dela fragmentos, significações e situações para serem confrontadas com a realidade contemporânea e situações reais da cronologia humana. Tal qual buscar significados que remetam a uma época anterior como, por exemplo, quando se liga Blackbird a uma forma de apoio à luta da população negra em prol de seus direitos, tal qual escreveu MacDonald, (1994) ${ }^{8}$.

De maneira geral, o jornalista brasileiro classifica as resenhas críticas em diferentes categorias: impressionistas, estruturalistas, concentradas no autor e as focadas no tema. Cada uma correspondendo a uma ideia de narrativa trazida por quem a escreve. Em cada caso, portanto, existe uma gama de atributos que agregam a sua significação e diferenciação, como explicaremos a seguir.

No caso da crítica estruturalista, esta visa analisar as características de construção do texto, omitindo-se (por assim dizer) de um posicionamento sobre o objeto analisado de fato. "Em geral, comete o equívoco de vender uma objetividade inatingível ao leitor e/ou abster-se de dizer-lhe qual a importância relativa de ler/ver/ouvir aquela obra" (PIZA, 2013, p.71); entretanto, elenca elementos textuais indiscutíveis para um debate acerca da obra, ou seja, cria uma boa base para a elaboração de uma discussão.

\footnotetext{
${ }^{8}$ No livro Revolution in the Head: The Beatles' Records and the Sixties, obra na qual o autor faz uma reflexão de uns dos artistas ocidentais mais famosos da história e sua ligação com os acontecimentos dentro da cultura e sociedade britânica durante os anos de 1960.
} 


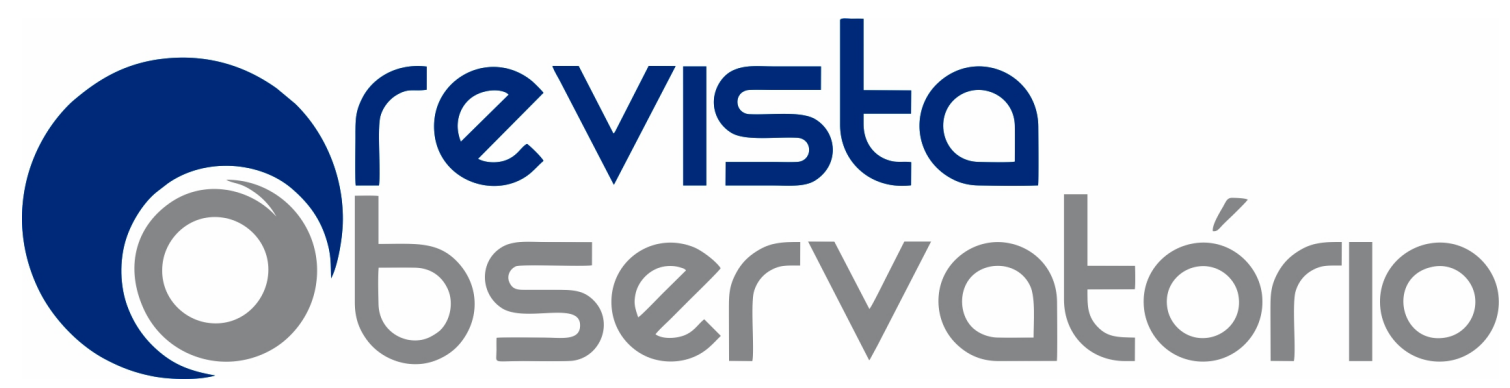

ISSN n² 2447-4266

Vol. 5, n. 6, Outubro-Dezembro. 2019

DOI: http://dx.doi.org/10.20873/uft.2447-4266.2019v5n6p453

Dentro desta perspectiva há, também, a resenha impressionista. Ela se baseia no tato sentimental do autor quando ele tem contato com a obra. Esta classificação baseia-se em uma honestidade e pontualidade do escritor com seu público, relatando tudo o que o próprio tirou do objeto analisado, curta e diretamente.

"Há também a resenha, muito comum no jornalismo brasileiro, que está mais concentrada em falar sobre o autor, sobre sua importância, seus modos, seus temas, sua recepção, do que em analisar aquela obra específica ou sua contribuição intelectual artística no conjunto" (PIZA, 2013, p.71). Considerando isso, apesar de reconhecer a falta de popularidade em seu uso, Piza pontua que essa é a classificação perfeita para debates sobre autores e suas carreiras. Consequentemente, podemos supor que esse também poderia ser o trampolim para a discussão acerca de estilos, ideias etc.

Por fim, a última classificação é voltada à história do objeto criticado. Semelhante à ideia de um making of, essa é construída através dos caminhos que levaram à obra, as suas influências e a maneira pela qual ela foi concebida. Debater a forma de produção e gerar, por conseguinte, reflexões sobre as temáticas trazidas, dificuldades e inspirações originadas ali; fazem parte da esfera desse último tipo de resenha.

\section{Aspectos teóricos e metodológicos da pesquisa}

A partir dos pressupostos introdutórios, optamos por trabalhar com a ótica teórico-metodológica da Recepção. Vislumbrando captar os efeitos produzidos pelas resenhas culturais presentes no corpus do estudo, utilizamos o filósofo 


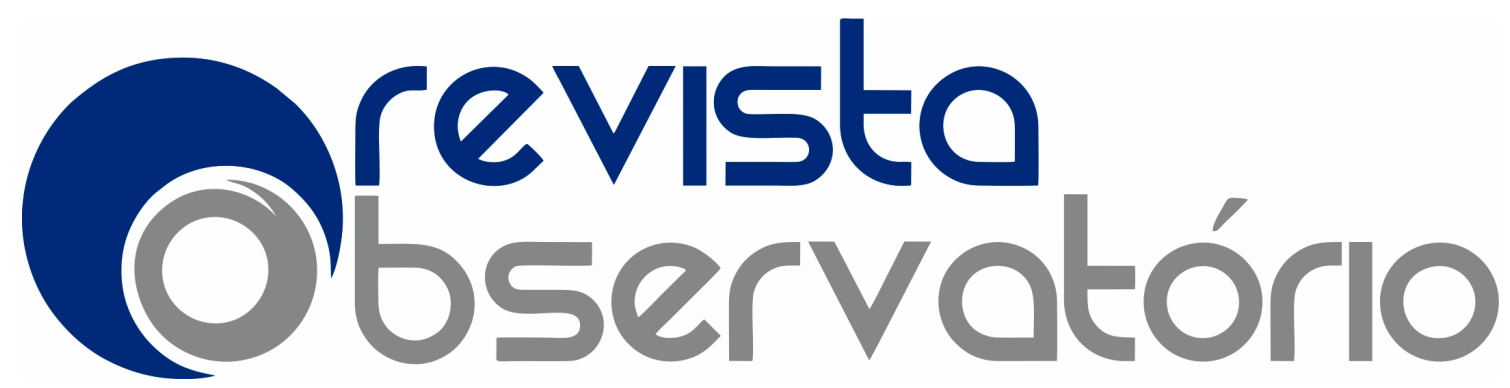

ISSN n² 2447-4266

Vol. 5, n. 6, Outubro-Dezembro. 2019

DOI: http://dx.doi.org/10.20873/uft.2447-4266.2019v5n6p453

estadunidense Kellner (2001) e o cientista da comunicação mexicano Orozco Gómez (2000), para guiar o cabedal teórico-metodológico trabalhado.

A contribuição de Douglas Kellner (2001) se dá em razão da análise das produções midiáticas, suas significações e efeitos. Estes pontos, então, podem ser encontrados através das categorias analíticas propostas pelo autor: horizonte social, campo discursivo e ação figural. Cada uma delas contribuirá para estabelecer o chão na sequência de análises.

O horizonte social contextualiza a época e o cenário em que se dá determinada produção midiática. O campo discursivo engloba os atores envolvidos no discurso dos veículos de comunicação de massa. Já a ação figural mostra o produto final de acordo com o horizonte social e o campo discursivo. Portanto, a partir de uma conjuntura específica e levando em conta os sujeitos envolvidos nesta, a mídia produz informação.

Do lado do intelectual mexicano, temos a contribuição do Modelo de Múltipla Mediação (2000), que lança mão da perspectiva do paradigma hermenêutico; ou seja, existe uma observação do pesquisador sobre a pessoa estudada (a partir de seu discurso) através de um aporte teórico. Destarte, os receptores e suas falas, durante o estudo, serão observados e analisados pelos pesquisadores envolvidos, os quais procurarão decifrar os sentidos a partir das teorias trabalhadas.

Portanto, a proposição teórica-metodológica do autor se baseia em analisar e entender como a audiência televisiva recebe as informações dos veículos transmitidos pela própria televisão. Faremos uso dos tipos de mediação para entender, então, o conteúdo trabalhado com os receptores selecionados neste estudo. 


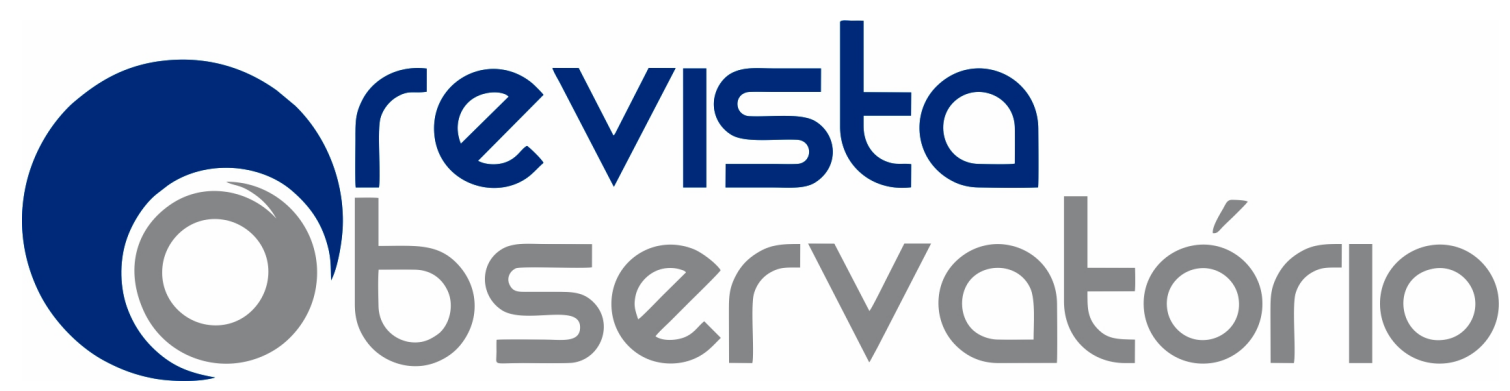

ISSN n² 2447-4266

Vol. 5, n. 6, Outubro-Dezembro. 2019

DOI: http://dx.doi.org/10.20873/uft.2447-4266.2019v5n6p453

A proposição do autor consiste em cinco categorias de mediação, que implicam a leitura dos sentidos em uma perspectiva individual (tomando como referência da produção de sentido, o receptor). As mediações individual (conceituações particulares), institucional (escola, família etc), meios de comunicação (efeitos das técnicas de manipulação, persuasão etc., que os veículos de comunicação dispõem e utilizam-se - consciente ou inconscientemente - para influenciar sua audiência), situacional (composta por elementos de uma situação específica como quantidade de pessoas, meio para ter contato com a produção midiática etc.), e de referência (faixa etária, etnia, gênero, orientação sexual etc., de cada receptor) compõem esta categorização de Orozco Gómez.

Levando em conta essas multimediações, o receptor apresenta códigos culturais específicos: a reprodução, quando aceita tudo o que recebe; a negociação, a partir do momento em que concorda com algumas partes daquilo a que está exposto e com outras não; e a resistência, processo em que não há aceite de propostas de sentido oriundas da mídia, o que acarreta uma produção alternativa ou contraproposta (Hall, 2003, apud CRUZ, GARCIA, 2016; p. 186).

É importante averiguar, portanto, em que condições as falas estão sendo constituídas e construídas. As "posições de enunciação" (HALL, 1996) são individuais e baseiam-se em um contexto particular e, ao mesmo tempo, público, ou seja, referem-se à identidade cultural de cada pessoa, que, cabe ressaltar, consiste em um processo sempre em construção, pois interage com o social.

Com o embasamento do pensador mexicano, é possível analisar diferentes aspectos que compõem a identidade de cada pessoa presente no estudo, especialmente pelo fato do conceito das múltiplas mediações ser intrinsecamente ligado à noção de cultura e à trajetória pessoal de cada receptor. 


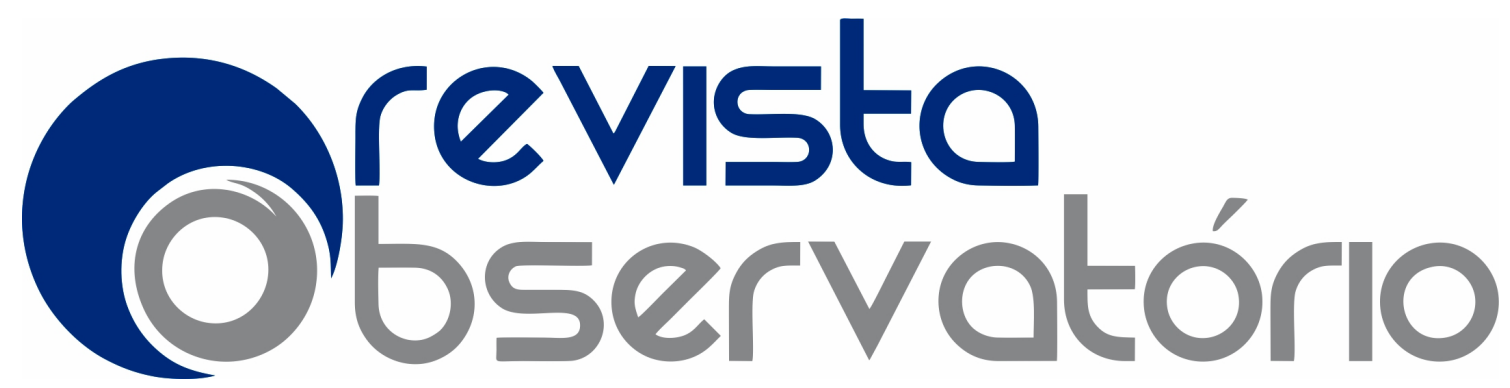

ISSN n² 2447-4266

Vol. 5, n. 6, Outubro-Dezembro. 2019

DOI: http://dx.doi.org/10.20873/uft.2447-4266.2019v5n6p453

Na concepção de Orozco Gómez, a perspectiva das mediações implica levar em conta toda uma soma de fatores que podem causar influência no processo de produção de sentido dos receptores. Conforme foi colocado acima, essas características ajudam a formar a identidade particular de cada um, a saber: a família, a escola, o grupo de amigos, o bairro, o trabalho, a cidade, os meios de comunicação e a disposição dos indivíduos frente a eles, seu nível de instrução, sexo, idade, etnia, religião, salário, classe social, ideologia etc.

Assim, através dessa identidade construída - e jamais acabada -, o receptor produzirá significados próprios, particulares e individuais. A total apropriação, a negociação ou até mesmo a resistência plena das mensagens são decorrentes diretas das diferentes mediações anteriormente citadas.

Sendo a escolha do aporte teórico a primeira etapa do estudo, seguiramse outros momentos: a seleção dos receptores, o encontro do grupo focal ${ }^{9}$ e a captação das informações individuais, para, então, chegarmos às análises e considerações finais do estudo.

Considerando isso, foram convidados a participar, como receptores, alunos matriculados ou já aprovados (ou seja, graduandos e graduados) nas disciplinas optativas de História Social do Rock I e História Social do Rock II, do curso de Jornalismo da Universidade Federal de Pelotas (UFPel). Na oportunidade, foram reunidas 13 pessoas, para debaterem sobre os textos selecionados, além do universo que tange a crítica musical.

Segundo Orozco Gómez (2000), o número mínimo de receptores é 10 quando desenvolvido um trabalho de recepção televisiva (neste estudo, a

\footnotetext{
${ }^{9}$ Reunimos os receptores em uma sala do campus Porto, da UFPel, antes de uma aula da disciplina de História Social do Rock. Quando realizamos a atividade de debate sobre as críticas musicais as quais compõe o estudo.
} 


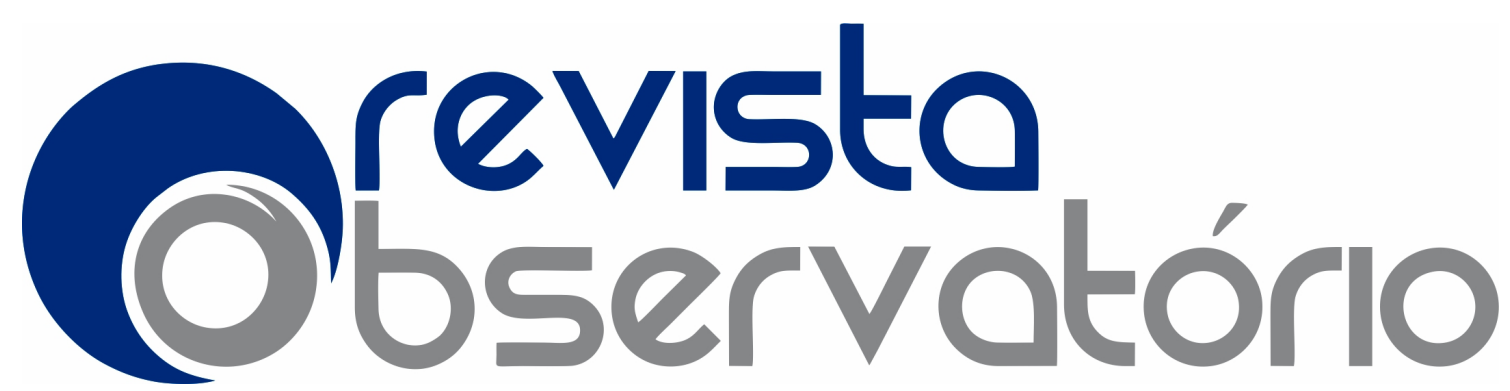

DOI: http://dx.doi.org/10.20873/uft.2447-4266.2019v5n6p453

aplicação dos pressupostos do autor será feita no jornalismo cultural, através das críticas musicais, como apontado anteriormente). Nesse sentido, foram convidadas 24 pessoas, mas, no entanto, somente $13^{10}$ confirmaram presença. Sendo assim, a quantidade de elementos não vai de encontro ao autor no que tange à coleta de informação.

Cabe ressaltar também que, no dia seguinte ao encontro com os receptores, enviamos um questionário para os participantes do estudo. Nele, coletamos dados como: idade, formação, grau de conhecimento do cantor Robert Plant, artistas que caracterizam o gosto musical do entrevistado, opinião sobre as críticas a artistas de rock na mídia tradicional, frequência e meios que consomem críticas e, por fim, a influência da crítica na visão do receptor sobre determinado artista.

\section{Primeiros passos da discussão e descrição das resenhas}

A última pergunta dentro do questionário indagava uma autorreflexão sobre a forma como cada receptor consome as resenhas críticas. Questionamos "até que ponto as críticas musicais influenciam a tua visão e as tuas escolhas quanto à música?", e, majoritariamente, os receptores negaram a influência e/ou classificaram-na como mínima. Mais: alguns deles criticaram a superficialidade e/ou a credibilidade de quem escreve, como disse Gabriel Huth,

Não consigo ver críticas jornalísticas como balizamento de qualidade ou descrição pra (sic) expressões artísticas de qualquer sorte e tampouco para a persona artista, ainda mais em música e ainda uma vez mais em rock, visto que arte, em seu âmago, é uma expressão interior do artista, sua perspectiva de algo traduzido em criação objetiva ou subjetiva que

${ }^{10}$ Cabe ressaltar que nem todas as falas foram utilizadas neste artigo. 


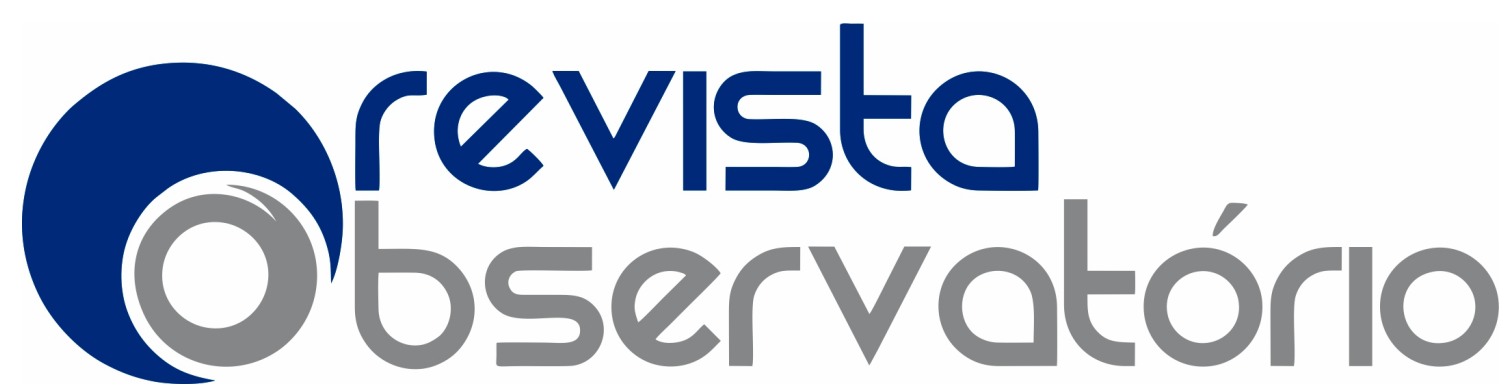

ISSN n² 2447-4266

Vol. 5, n. 6, Outubro-Dezembro. 2019

DOI: http://dx.doi.org/10.20873/uft.2447-4266.2019v5n6p453

causa uma reação em quem recebe este produto. Desta forma, o que para uns é um lixo, para outros é um luxo; sendo, portanto, impossível a qualquer pessoa descrever um trabalho sem impressões influenciadas pelas experiências e vivências pessoais. Tanto para o artista quanto seu trabalho, as críticas não alcançam uma verdade universal sobre sua obra, e por ver sob esta ótica, não as acompanho, tanto em mídia tradicional quanto alternativa.

Então, podemos perceber que o texto crítico está sujeito à interpretação dos próprios leitores e de suas trajetórias de vida. Isto é, a "bagagem" individual influencia necessariamente o modo de compreensão do receptor sobre os sentidos dentro da resenha. A discordância para com o que propõe um crítico significa que o leitor em questão não se vê representado pelos elementos trazidos no texto do crítico.

A partir disso, iniciaremos a principal discussão do trabalho, a relação dos receptores com a crítica musical. Existe uma relevância das resenhas críticas para o público apreciador de rock? Elas cumprem o seu papel? Como é o debate desse público quando se depara com um texto crítico a um disco? Antes de darmos início à análise dos eventos para responder às perguntas, é necessário descrever as resenhas críticas para melhor ilustrar o que estava sendo dialogado entre os receptores. Iniciaremos, então, com a descrição da crítica publicada pelo jornal inglês sem vírgula aqui The Guardian.

\section{A crítica do veículo britânico}

A crítica pode ser considerada uma nota, por conta do tamanho e da falta de aprofundamento a qualquer ponto. Escrita por Phil Mongredien, o autor é extremamente sucinto em suas frases. Pontua uma linearidade entre o disco Carry Fire e o Lullaby and... the Ceaseless Roar (long-play lançado em 2014, sendo o penúltimo trabalho de estúdio de Plant). 


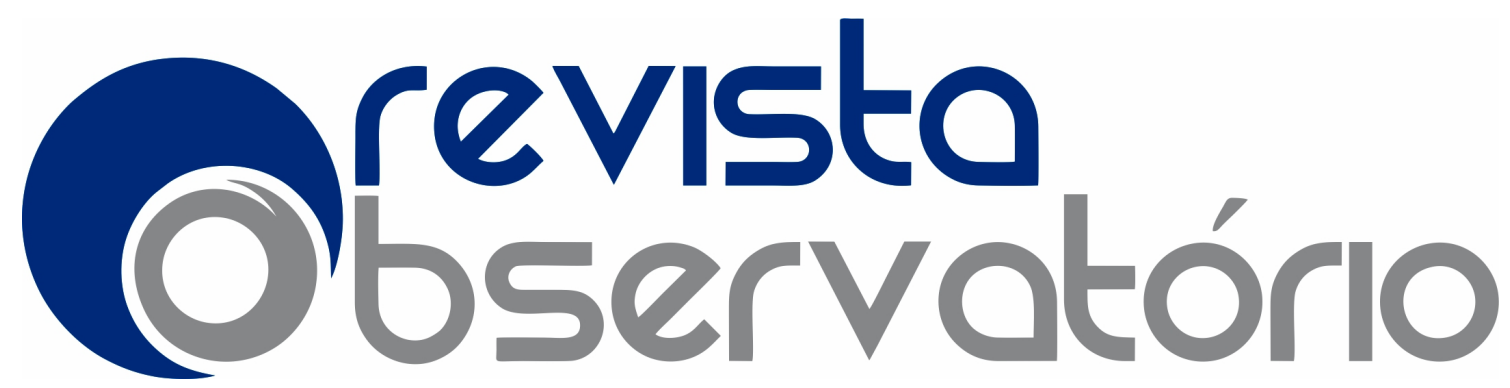

ISSN n² 2447-4266

Vol. 5, n. 6, Outubro-Dezembro. 2019

DOI: http://dx.doi.org/10.20873/uft.2447-4266.2019v5n6p453

Ademais, o crítico inglês destaca também a participação da banda de apoio do cantor britânico, The Sensational Space Shifters. Segundo ele, o grupo contribui para completar os elementos musicais entre rock e folk trazidos por Plant. Chega a ressaltar o uso de Bendir, Djembe e Oud, dois instrumentos de origem africana e um de origem árabe, como forma de pontuar atributos da sonoridade do álbum.

Na sequência, Mongredien faz uma comparação envolvendo as músicas New World e Immigrant Song ${ }^{11}$. De maneira que seriam contrastantes, ele utiliza os termos yin e yang, como forma de tornar as canções uma oposta à outra. Além disso, o escritor ainda pontua "Lyrically Carry Fire"12 sees Plant address bigger issues, whether the evils of colonialism on New World or nationalism on Carving Up the World Again"13. Ou seja, o crítico traz (mesmo que sutilmente) suas impressões das temáticas trabalhadas pelo músico na obra.

Por fim, a crítica do veículo inglês termina com menções honrosas às canções Bluebird Over The Mountain e The May Queen. O álbum foi avaliado com nota 4 estrelas, sendo que - vale ressaltar - dentro da avaliação o máximo possível a ser atingido são 5 estrelas.

\section{A resenha do veículo brasileiro}

Enquanto a primeira resenha crítica apresentada no trabalho tem poucas linhas, a brasileira tem um corpo de texto bastante maior. Em contrapartida, a nota é exatamente igual: 4 de 5. Escrita por Felipe Cotta, a linha de apoio sob o

\footnotetext{
${ }^{11}$ Immigrant Song faz parte do arsenal musical da banda pregressa de Plant, o Led Zeppelin. A canção foi lançada no disco Led Zeppelin III, de 1970.

12 Itálico utilizado pelo crítico.

13 Tradução livre: "liricamente Carry Fire vê Plant abordar questões maiores, ou os males do colonialismo em New World ou nacionalismo em Carving Up the World Again.
} 


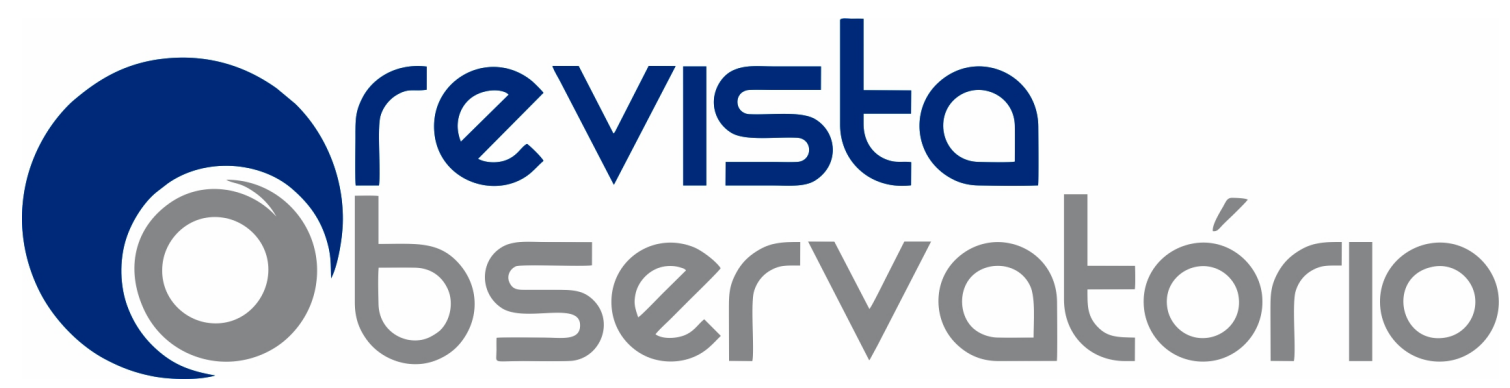

título "Robert Plant - Carry Fire" é: "vocalista celebra o presente respeitando o passado".

Já no primeiro parágrafo, o redator destaca a sabedoria do cantor na forma de cantar e distribuir sua voz ao longo do álbum. Em seguida, começa a diferenciar o "Plant de 45 anos atrás" do estágio atual no qual se encontra o vocalista inglês. Mesmo assim, o autor traz referências dos trabalhos de Robert Plant do início de sua carreira solo, do meio e do princípio de sua carreira (dessa vez, com o Led Zeppelin).

Cotta, até o terceiro parágrafo do texto, comenta bastante sobre as impressões gerais que sentiu e informa sobre a banda de apoio ser o The Sensational Space Shifters. "Bastante melancólico", "sabor refinado" e "pouco para se preocupar e muito para compartilhar" são caracterizações utilizadas para uma descrição em uma visão macro do long-play.

A partir daí, dos cinco parágrafos remanescentes, três abordam músicas destacadas pelo próprio crítico. Neste sentido, Cotta utiliza suas descrições e impressões para dar novos atributos ao disco. No entanto, ele o faz numa visão mais lírica e específica dentro de determinadas partes da obra. Além de falar do álbum, o autor aborda as características pessoais de Plant no seu modo de ver, obviamente.

Por fim, o ato final se dá, logicamente, no último parágrafo, quando o crítico faz uma certa contemplação ao artista que é Robert Plant e sacramenta a nota alta dada a Carry Fire.

\section{Análises e discussões gerais}

Em um primeiro momento, organizamos a sala com cadeiras em formato circular e deixamos o disco Carry Fire tocando em um aparelho de som. Foram distribuídas as resenhas de maneira impressa para cada participante do grupo 


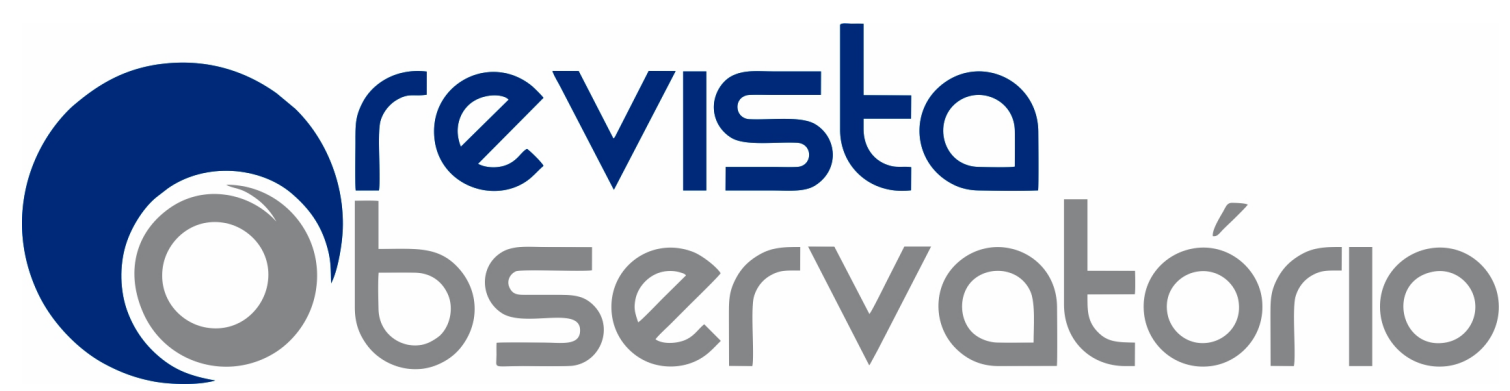

focal e, posteriormente, explicamos como o estudo ocorreria. Após cerca de 15 minutos aguardando todos chegarem, e dando tempo para que os que não haviam lido o material o lessem, iniciamos o trabalho.

Foram 53 minutos de discussão, que mediamos sem tecer comentários acerca do disco, das resenhas ou dos espaços argumentativos de cada receptor presente. Nossas intervenções ocorriam quando o assunto se distanciava demais da discussão, algo que aconteceu duas vezes ${ }^{14}$.

Com as informações recebidas através do questionário, descobrimos que todos os presentes conheciam Robert Plant. A esmagadora maioria conhecia e ouvia apenas os seus trabalhos do Led Zeppelin com regularidade - mas ainda o acompanhava em algum grau - e, do outro lado, poucos não eram fortemente familiares com sua carreira.

Os receptores participantes demoraram a se manifestar com maior proatividade. Quem iniciou a discussão foi Luis Artur ${ }^{15}$, comentando que a crítica de Felipe Cotta não traz nada de novo "e é muito parecido com o que se faz em termos de texto crítico há algumas décadas". Em consonância com o que disse o primeiro participante, Estevan ${ }^{16}$ ressaltou a quantidade de usos de estereótipos nas críticas de discos de rock, de maneira geral.

As falas deles tiveram repercussão e mais receptores começaram a emitir suas opiniões. As frases eram frequentemente formadas por uma ideia que desaguava em expressões como "estereótipo", "comum" e "falta de informação". Havia uma convergência de opiniões para um consenso: faltava conteúdo.

\footnotetext{
${ }^{14}$ A primeira intervenção foi necessária aos 17 minutos e outra ao final, para terminar a sessão de debate. Na primeira intervenção, foi explicado (partindo de uma abordagem de Piza, 2013) o que compreendemos como responsabilidade da crítica.

${ }^{15}$ Professor de história, 43 anos.

16 Jornalista e mestrando em Sociologia, 23 anos.
} 


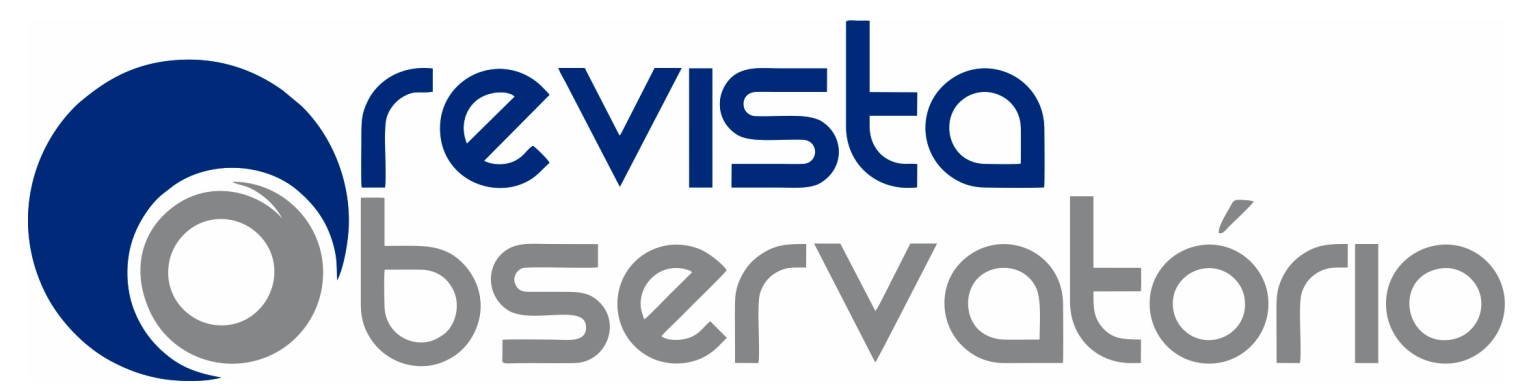

ISSN n² 2447-4266

Vol. 5, n. 6, Outubro-Dezembro. 2019

DOI: http://dx.doi.org/10.20873/uft.2447-4266.2019v5n6p453

"O texto do Guardian é uma nota. Algo muito superficial, por mais que cite alguma coisa aqui ou ali, falta informação. Não te traz nada de conteúdo. A crítica do Omelete - aí, sim, uma crítica - consegue dar algo pro (sic) leitor, mas ainda muito superficial", apontou Carlos André ${ }^{17}$. Na medida em que a discussão tinha mais participantes, o debate parecia chegar a um consenso sobre isso.

Então, Douglas ${ }^{18}$ abordou em sua fala o saudosismo presente nos textos críticos sobre rockstars mais antigos. Segundo ele, nenhum artista novo jamais conseguirá ser equiparado a músicos como Plant, por conta da contemplação em torno desses consagrados nomes. Para esse receptor, isto é negativo porque corrobora com a criação de novos estereótipos e menos horizontalidade nas informações.

Matheus ${ }^{19}$ trouxe uma visão jornalística de que sempre será feito um apanhado da carreira do artista, mas também acredita que o autor teve alguma preguiça ao escrever por "caminhos óbvios". Disse acreditar, também, que o fato de estar em um portal como o Omelete "há tendência de funcionar mais como um guia do que como um texto técnico. Vai trazer referências mais comuns do que oferecer uma visão diferente".

Aos poucos, o debate rumou para uma conversa sobre a construção do texto. Alguns defendiam que muitas críticas tentam passar uma impressão erudita, mas falham na obrigação de passar informações, enquanto outros acreditam que as críticas costumam pecar na perspectiva de dar informações e criticar construtivamente de fato. Carlos André exemplificou, afirmando que o próprio autor da resenha brasileira se mostrou bastante fã de Plant: "a única parte

\footnotetext{
17 Jornalista e professor universitário, 48 anos.

${ }^{18}$ Mecânico, músico e estudante de história. 36 anos.

19 Jornalista, 22 anos.
} 


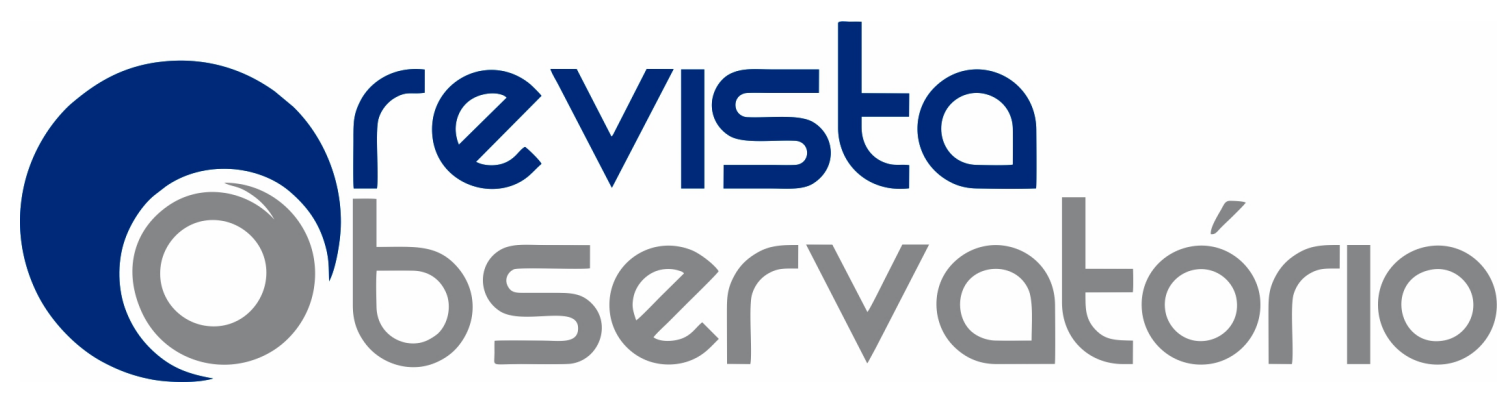

em que ele faz uma crítica - que é quando ele critica a banda de apoio - é abafada. Então, deixa de ser crítico. É um texto que só elogia".

Durante a nossa análise dos questionários, contabilizamos que absolutamente nenhum dos receptores consome críticas de música com frequência. O contato com elas se dá pela internet, através de sites de cultura e/ou música que acessam; além disso, nenhum se sente representado pelas que lê. A principal justificativa passa pela utilização de estereótipos por parte dos críticos e a distância deles com o que está sendo criticado.

Eventualmente, Tabaquara $^{20}$ opinou que parte das indignações constatadas pelos outros participantes às críticas de rock são advindas da popularidade do gênero musical no Brasil. Para ele, o fato de sertanejo, sertanejo universitário, funk carioca e pop terem públicos muito grandes, tocarem nas rádios e obterem fidelidade (shows lotados, produtos comprados etc) por parte de seus consumidores, corrobora para a crítica não ser tão presente e bem executada no meio do rock'n'roll. Visto que, por esta ótica, haveria mais motivos para se falar desses outros estilos de música.

Chegando à parte analítica inspirada em Kellner (2001), partimos do cenário no qual podemos visualizar facilmente que o lançamento do disco Carry Fire se enquadra como o horizonte social, exatamente por ser o elemento que contextualiza o momento analisado. Enquanto isso, o campo discursivo é composto pelos dois autores, os dois portais das resenhas críticas e seus leitores, por Plant e os Sensational Spaceshifters.

Por fim, a ação figural é diferente em cada uma delas. Existe uma contemplação do artista, do lado do portal brasileiro, trazendo elementos estereotipados. $O$ fato de citar e retornar diversas vezes

\footnotetext{
${ }^{20}$ Bacharel em direito e estudante de jornalismo, 30 anos.
} 


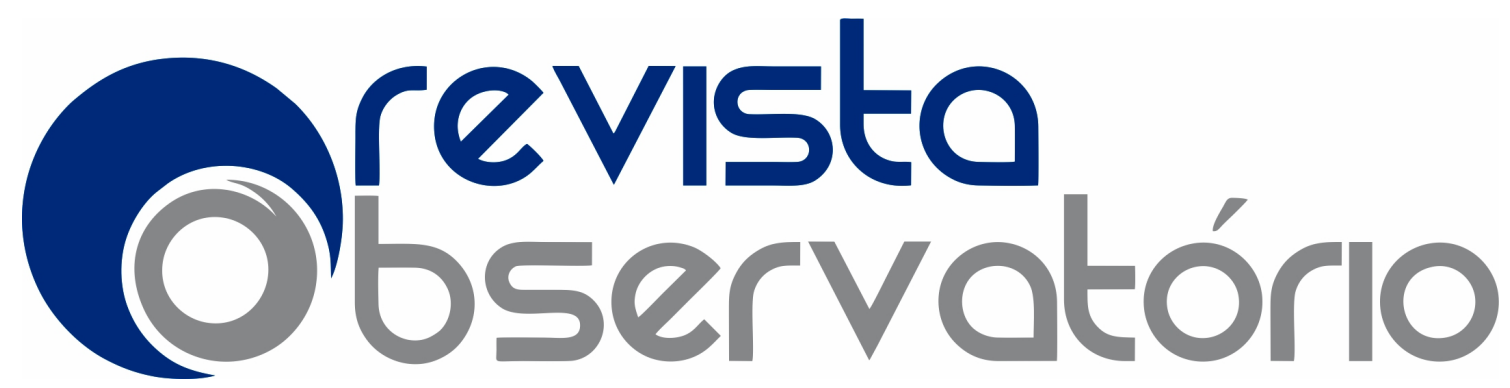

ISSN n² 2447-4266

Vol. 5, n. 6, Outubro-Dezembro. 2019

DOI: http://dx.doi.org/10.20873/uft.2447-4266.2019v5n6p453

o que deixa dúvida sobre a idoneidade de todos os pilares da argumentação do crítico brasileiro é o excesso de adjetivação durante sua resenha. Nitidamente, o autor é um admirador da carreira e obra de Robert Plant. Isso pode, sim, afetar sua percepção sobre o álbum e dificultar na análise de pontos negativos. Esta dúvida paira ainda mais por conta da data de publicação: 13 de outubro de 2017, exatamente a data de lançamento do disco. (CRUZ, PIRES, 2018, p.1001)

Já a publicação britânica, em que pese o fato de esta ser caracterizada como uma nota, é omissa no dever de informar questões básicas do jornalismo. neste sentido, apresenta descaso em relação aos preceitos elencados por Piza (2013) em se tratando de crítica cultural.

Então, podemos assumir que, em ambos os casos, a ação figural se configura nos reflexos declarados pelos receptores. Uso frequente dos estereótipos sobre o cantor e a falta de descrição dos elementos musicais encadeiam o produto da categoria. Nenhum dos integrantes do grupo focal classificou como boa qualquer uma das críticas apresentadas, o que corrobora com nossa percepção da discussão dos participantes.

Além disso, o constante uso do passado do artista traz a dúvida aos receptores sobre o conhecimento dos resenhistas quanto ao cantor Robert Plant, visto que o Led Zeppelin teve seu fim em 1980 e o vocalista gravou nada menos do que 11 discos como artista solo. Contemplações e uso do passado do artista geraram muitas críticas dos participantes do estudo.

\section{Considerações finais}

Notamos há notórias diferenças de idade entre os receptores deste trabalho, seja em termos de idade (mediação estrutural), crenças (mediação cognitiva) e trajetórias (mediação cultural). Mesmo assim, percebemos que seus posicionamentos, majoritariamente, são consonantes. Considerando isso, em 


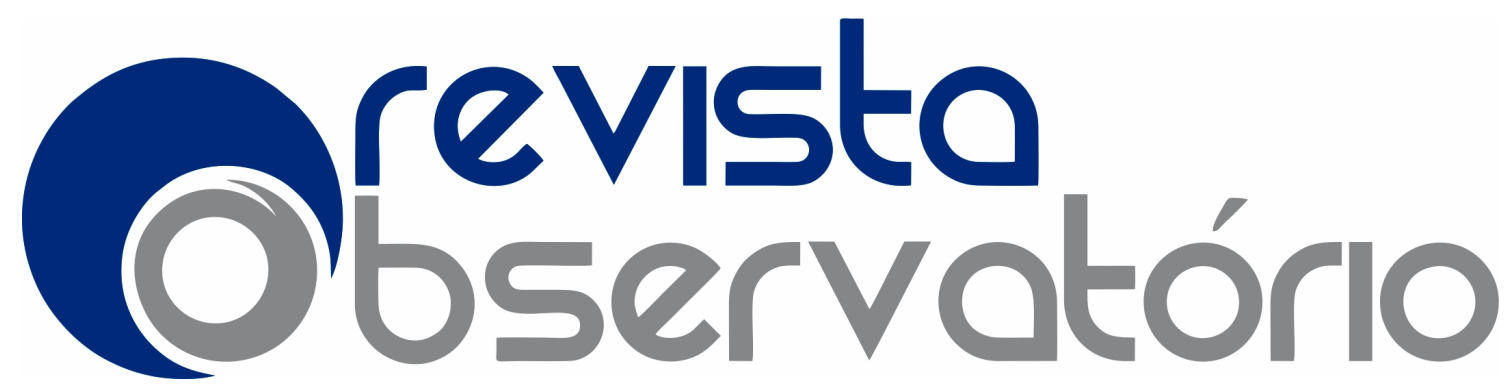

DOI: http://dx.doi.org/10.20873/uft.2447-4266.2019v5n6p453

nível geral, a disposição preponderante é a de resistência, uma vez que a grande maioria se opõe ao conteúdo proposto pelas críticas.

Tal visão é corroborada pela fala de um dos nossos entrevistados, citada anteriormente ${ }^{21}$, que sumariza o principal ponto do debate, que é a subjetividade artística arbitrariamente limitada pela visão do resenhista. Nela, constatamos que as duas ações figurais, apesar de distintas convergem na estereotipação do disco, bem como do artista.

Contrariando o que Piza (2013) atribui como responsabilidades do jornalismo cultural, e neste as diferentes formas de resenha, ambas as críticas pecam no objetivo de fornecer ao leitor subsídios além do, dito anteriormente, estereótipo. Nesta realidade complexa, em que atuam diferentes fontes e origens, a cultura é eleita "a grande mediadora de todo processo de produção comunicativa" (OROZCO GÓMEZ, 2000: 114). Portanto, a comunicação vai além dos meios; ela desloca-se para as (multi) mediações, que, por sua vez, são permeadas pela cultura. Assim, todos os processos sociais são perpassados pela cultura. Ela é o agente central de mediação.

\section{Referências Bibliográficas}

COTTA, Felipe. Robert Plant - Carry Fire. Crítica. Disponível em $<$ https://omelete.uol.com.br/musica/critica/robert-plant-carry-fire-critica/>. Acesso em 25 dez. 2017.

CRUZ, Fábio; PIRES, Arthur Freire Simões. A Way With Words: um estudo barthesiano sobre Carry Fire. Revista Observatório, Palmas, v. 4, n. 6, p.985-1006, out.- dez. 2018. Trimestral.

CRUZ, Fábio Souza da; CURI, Guilherme de Oliveira. Communication Breakdown: a cobertura do show de Robert Plant no festival Lollapalooza à luz do fait divers.

${ }^{21}$ Gabriel Huth. 


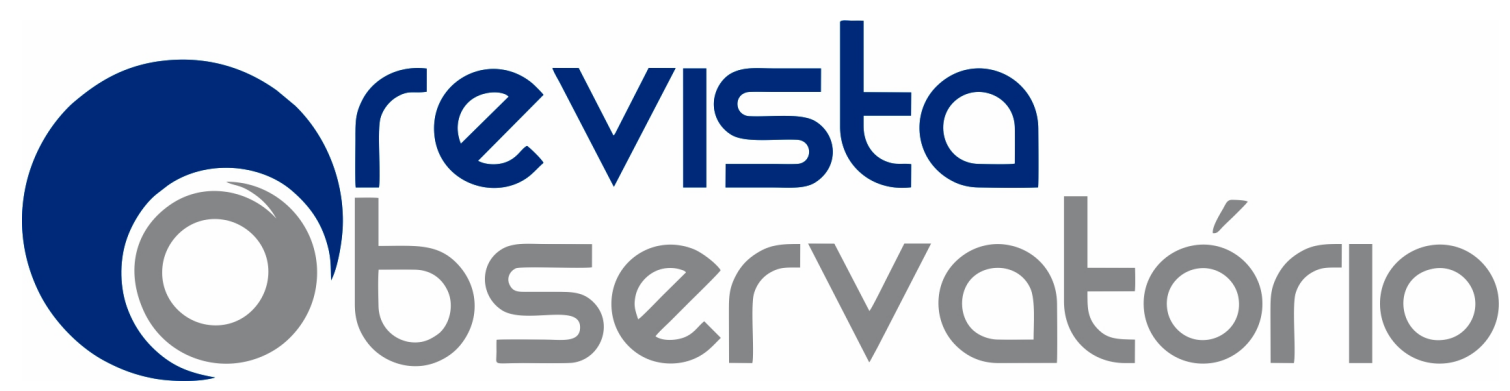

DOI: http://dx.doi.org/10.20873/uft.2447-4266.2019v5n6p453

Revista Famecos: mídia, cultura e tecnologia, Porto Alegre, v. 22, n. 4, p.71-85, out. 2015.

CRUZ, Fábio Souza da; GARCIA, Estevan Freitas. A donzela estereotipada: um estudo de recepção do Grupo Iron Maiden nos portais G1 e R7. Animus: Revista Interamericana de Comunicação Midiática, Santa Maria, v. 16, n. 31, p.178-195, 2017. Anual.

KELLNER, Douglas. A cultura da mídia. São Paulo: EDUSC, 2001.

MONGREDIEN, Phil. Robert Plant: Carry Fire review - more of a good thing.

Disponivel em <https://www.theguardian.com/music/2017/oct/15/robertplantcarry- fire-review>. Acesso em 25 dez. 2017.

OROZCO GÓMEZ, Guillermo. La investigación em comunicación desde La perspectiva cualitativa. La Plata: Ediciones de La Facultad de periodismo y Comunicación Social, 2000.

PIZA, Daniel. Jornalismo Cultural. São Paulo: Contexto, 2013.

https://www.forbes.com/sites/markbeech/2018/01/27/led-zeppelin-adds-to-300million-sales-with-live-album-50th-anniversary-surprises/\#116ea753ca59

https://www.rockhall.com/inductees 